\title{
KESULITAN SISWA DALAM MENYELESAIKAN SOAL ARITMATIKA SOSIAL DI KELAS VII SMP NEGERI 11 MUARO JAMBI
}

\author{
Ika Kurniati ${ }^{1}$, Hasan Basri Said ${ }^{2}$, Akhmad Faisal Hidayat ${ }^{3}$ \\ Program Studi Pendidikan Matematika, FKIP, Universitas Batanghari ${ }^{1,2,3}$ \\ J1. Slamet Riyadi No.1 Broni Jambi \\ Email: ikakurniati50@gmail.com
}

\begin{abstract}
ABSTRAK
Tujuan dari penelitian ini ialah untuk mengetahui kesulitan siswa dalam menyelesaikan soal aritmatika sosial pada pemahaman konsep, keterampilan, prinsip dan fakta yang digunakan di kelas VII SMP Negeri 11 Muaro Jambi. Subjek penelitian ini ialah dua subjek yang diambil dari kelas VII D yang memiliki nilai rata-rata terendah pada Ulangan Harian materi aritmatika sosial tahun ajaran 2019/2020. Instumen dalam penelitian ini adalah lembar soal aritmatika sosial dan pedoman wawancara. Hasil dari penelitian menunjukkan terdapat kesulitan siswa pada pemahaman konsep, keterampilan, prinsip dan fakta yang digunakan dalam menyelesaikan soal aritmatika sosial. Siswa yang mengalami kesulitan dalam pemahaman konsep seperti kesulitan saat menyatakan ulang suatu konsep. Kesulitan dalam mengklasifikasikan soal yang diberikan berkaitan dengan yang ada pada materi, siswa hanya menyatakan satu materi dari dua materi yang terkait pada soal yang diberikan. Kesulitan dalam menyajikan konsep pada berbagai representasi matematika, siswa mengoperasikan satuan harga dengan berat serta mengoperasikan langsung satuan harga dengan bentuk persen. Kesulitan siswa terkait dengan fakta matematika meliputi kesulitan dalam penulisan beberapa simbol yang digunakan. Kesulitan siswa terkait dengan keterampilan dapat dilihat dari kesulitan siswa dalam operasi hitung perkalian, penjumlahan, dan penulisan nilai tempat bilangan, serta kesulitan dalam mengoperasikan penjumlahan nilai jutaan. Kesulitan siswa terkait dengan prinsip dapat dilihat antara lain siswa tidak mengingat rumus yang digunakan, siswa tidak memahami konsep dan lambang yang digunakan, siswa juga tidak menggunakan rumus yang bersesuaian dengan apa yang ditanyakan dari soal yang diberikan.
\end{abstract}

Kata Kunci:

Aritmatika Sosial; Kesulitan Siswa; Keterampilan, Fakta dan Prinsip; Pemahaman Konsep.

\begin{abstract}
The purpose of this study is to determine the difficulty of students in solving social arithmetic problems in understanding the concepts, skills, principles and facts used in class VII SMP Negeri 11 Muaro Jambi. The subjects of this study were two subjects taken from class VII D who had the lowest average value in the Daily Repetition of social arithmetic material for the 2019/2020 school year. The instrument in this study was a social arithmetic question sheet and interview guidelines. The results of the study indicate there are difficulties students have in understanding the concepts, skills, principles and facts that are used in solving social arithmetic problems. Students who experience difficulties in understanding concepts such as difficulties when restating a concept. Difficulties in classifying the questions given relate to those in the material, students only state one material from two materials related to the problem given. Difficulties in presenting concepts in various mathematical representations, students operate unit prices with weight and directly operate unit prices in the form of percent. Student difficulties related to mathematical facts include difficulties in writing some of the symbols used. Student difficulties related to skills can be seen from students' difficulties in calculating multiplication, addition, and writing values of place numbers, and difficulties in operating the sum of millions. Student difficulties related to principles can be seen, among others, students do not remember the formulas used, students do not understand the concepts and symbols used, students also do not use formulas that correspond to what is asked of the questions given.
\end{abstract}

Keywords:

Social Arithmetic; Student Difficulties; Skills, Facts and Principles; Concept Understanding. 


\section{$\pi$ (Phi)}

\section{PENDAHULUAN}

Belajar merupakan tindakan dan perilaku siswa yang kompleks, sebagian tindakan belajar hanya dialami oleh siswa sendiri. Belajar dikatakan berhasil jika siswa mampu mengulangi kembali materi yang telah dipelajarinya dan mampu menyampaikan materi yang diekspresikan menggunakan bahasa sendiri serta terlihat tanda-tanda perubahan prilaku manusia sebagai akibat terjadinya proses pembelajaran. Pada proses pembelajaran matematika, tentunya siswa sering mengalami hambatan. Hambatan tersebut merupakan kesulitan yang dihadapi oleh siswa sehingga dapat mengganggu proses pembelajaran yang akan membuat siswa sulit menyerap materi yang diajarkan guru.

Salah satu topik pembelajaran matematika yang sering dijumpai dalam kehidupan sehari-hari adalah Aritmatika Sosial. Aritmatika sosial sering dijumpai dalam kehidupan sehari-hari seperti penjualan, pembelian, keuntungan, kerugian, bunga, pajak, bruto, neto, dan tara. Dilihat dari rata-rata nilai ulangan harian aritmatika sosial dari beberapa kelas VII di SMP Negeri 11 Muaro Jambi pada semester genap tahun pelajaran 2019/2020 menunjukkan nilai rata-ratanya masih dibawah stantdar ketuntasan. Hal ini menunjukkan siswa mengalami kesulitan pada materi aritmatika sosial.

Tabel 1. Rata-rata UH Aritmatika Sosial di SMP Negeri 11 MuaroJambi Pada Semester Genap Tahun Pelajaran 2019/2020.

\begin{tabular}{ccc}
\hline No & Kelas & $\begin{array}{c}\text { Rata-rata Nilai UH Aritmatika } \\
\text { Sosial }\end{array}$ \\
\hline 1 & VII A & 54,68 \\
2 & VII B & 47,88 \\
3 & VII C & 47,2 \\
4 & VII D & 28,92 \\
5 & VII E & 47,34 \\
6 & VII F & 47,22 \\
\hline \multicolumn{2}{l}{ Sumber Buku Absensi Siswa Daftar Nilai Siswa }
\end{tabular}

Program Mingguan

Djamarah (2011) mengemukakan kesulitan belajar adalah suatu kondisi di mana anak didik tidak dapat belajar secara wajar, disebabkan adanya ancaman, hambatan ataupun gangguan dalam belajar. Kesulitan dalam pembelajaran matematika dapat dilihat dari objek yang dipelajari dalam pembelajaran matematika. Gagne (Andar \& Ikman, 2016) objek matematika yang diperoleh siswa terdiri dari objek langsung dan tak langsung. Objek langsung terdiri dari fakta (fact), konsep (concept), prinsip (principle), dan keterampilan (skill).

Gazali (2016) menyatakan fakta merupakan suatu konvensi atau kesepakatan dalam matematika, ide matematika yang disajikan misalnya dalam kata-kata atau lambang (simbol) matematika. Konsep dalam matematika ialah ide abstrak yang memungkinkan seseorang dapat mengklasifikasikan objekobjek atau pristiwa tersebut merupakan contoh atau bukan contoh dari ide abstrak tersebut (Andar \& Ikman, 2016). Menurut Bell (Gazali, 2016) mengemukakan prinsip merupakan hubungan antara konsep bersama dengan relasi di antara objekobjek. Andar \& Ikman (2016) keterampilam merupakan kemampuan untuk menggunakan prosedur atau langkah-langkah untuk menyelesaikan suatu soal. Judul penelitian ini adalah kesulitan siswa dalam menyelesaikan soal aritmatika sosial di kelas VII SMP Negeri 11 Muaro Jambi.

\section{METODE PENELITIAN}

Berdasarkan tujuan penelitian maka penelitian ini termasuk ke dalam jenis penelitian kualitatif. Pendekatan dalam penelitian ini menggunakan pendekatan deskriptif. Sugiyono (2017) mengemukakan penelitian deskriptif merupakan jenis penelitian untuk memandu peneliti mengekplorasi atau memotret situasi sosial yang akan diteliti secara meneluruh, luas dan mendalam. Penelitian ini dilakukan terhadap kelas yang memiliki nilai ulangan harian 
terendah dari enam kelas VII di SMP Negeri 11 Muaro Jambi.

Teknik pemilihan subjek yang digunakan dalam penelitian ini adalah teknik purposive sampling. Menurut Arikunto (2002) teknik ini biasanya dilakukan berdasarkan beberapa pertimbangan misalnya alasan keterbatasan waktu, tenaga, dan dana sehingga tidak dapat mengambil sampel yang besar dan jauh. Dalam penelitian ini yang akan dijadikan subjek penelitian adalah dua siswa dari kelas yang memiliki nilai ulangan harian terendah. Dua subjek ini diambil berdasarkan banyaknya kesalah yang dilakukan saat menyelesaikan tes kesulitan siswa dalam menyelesaikan soal aritmatika sosial pertama.

Instrument peneltian adalah alat atau fasilitas yang digunakan oleh peneliti dalam mengumpulkan data agar mempermudah pekerjaan. Adpun instrument yang digunakan dalam penelitian ini ialah lembar soal aritmatika sosial dan pedoman wawancara, lembar soal aritmatika sosial yang diberikan merupakan soal uraian. Tes dilakukan sebanyak dua kali, setelah pemberian tes peneliti mendapatkan data berupa lembar jawaban siswa selanjutnya data tersebut diwawancarai sehingga mendapatkan data berupa transkip wawancara, proses ini dilakukan sampai peneliti mendapatkan data yang valid (konsisten).

Data yang diperoleh dilakukan analisis untuk menyesuaikan kesulitan siswa pada pemahaman konsep, fakta, prinsip dan keterampilan yng disesuaikan dengan indikator yang digunakan. Setelah mendapatkan data, data tersebut direduksi berarti merangkum, memilih hal-hal pokok, fokus pada hal penting, mencari kesulitan belajarnya dan membuang data yang tidak perlu. Data yang telah direduksi akan memberikan gambaran yang lebih jelas, mempermudah peneliti melakukan pengumpulan data selanjutnya, dan mencarinya bila diperlukan. Data yang sudah direduksi selanjutnya disajikan dalam bentuk tabel yang mengklasifikasikan pada keslitan yang dialami siswa dalam pemahaman konsep, fakta, keterampilan dan prinsip. Tahap selanjutnya ialah melakukan penarikan kesimpulan dari data yang ada.

\section{HASIL DAN PEMBAHASAN}

Hasil penelitian ini berupa lembar jawaban siswa dan transkp wawancara berikut merupakan ringkasan dari jawaban dan transkip wawancara yang diperoleh.

Tabel 2. Kesulitan Subjek dari S1 dalam Menyelesaikan Soal

\begin{tabular}{|c|c|}
\hline $\begin{array}{l}\text { Pemahaman } \\
\text { Konsep }\end{array}$ & 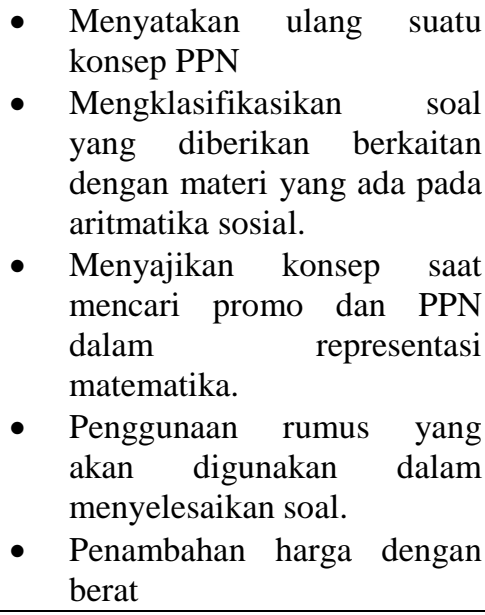 \\
\hline Fakta & $\begin{array}{ll}\text { - } & \text { Menuliskan simbol pada nilai } \\
\text { jutaan } \\
\text { - } \\
\text { Menuliskan simbol pada } \\
\text { persentase tara }(\% \mathrm{~T})\end{array}$ \\
\hline Keterampilan & 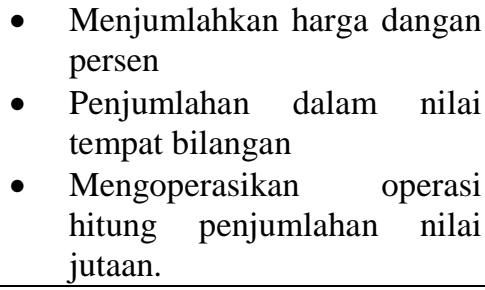 \\
\hline Prinsip & $\begin{array}{l}\text { - Mengingat rumus yang } \\
\text { digunakan. } \\
\text { Memahami konsep dan } \\
\text { lambang yang digunakan. } \\
\text { - Menggunakan rumus yang } \\
\text { bersesuaian dengan apa yang } \\
\text { ditanyakan. }\end{array}$ \\
\hline
\end{tabular}




\section{$\pi$ (Phi)}

Tabel 3. Kesulitan Subjek dari S2 dalam Menyelesaikan Soal

\begin{tabular}{|c|c|}
\hline $\begin{array}{l}\text { Pemaha } \\
\text { man } \\
\text { Konsep }\end{array}$ & 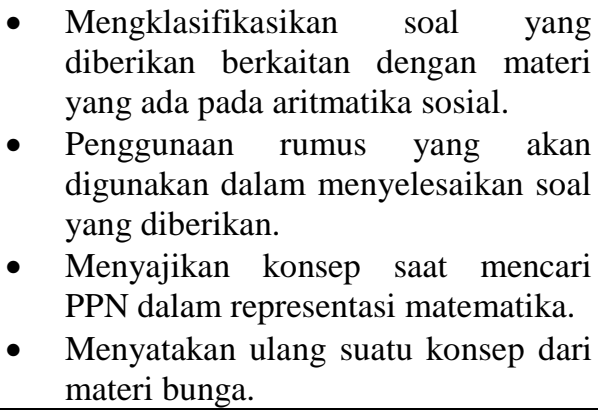 \\
\hline Fak & $\begin{array}{l}\text { - Menuliskan simbol modal awal, } \\
\text { persen dan bulan. } \\
\text { Menuliskan simbol pada persentase } \\
(\% \mathrm{~T})\end{array}$ \\
\hline $\begin{array}{l}\text { Keteram } \\
\text { pilan }\end{array}$ & $\begin{array}{l}\text { - Mengoprasikan operasi hitung } \\
\text { perkalian } \\
\text { - Mengurangkan langsung suatu harga } \\
\text { dengan bentuk persen }\end{array}$ \\
\hline Prinsip & $\begin{array}{llr}\text { - } & \text { Mengingat rumus yang digunakan. } \\
\text { - } & \text { Memahami konsep dan lambang } \\
\text { yang digunakan. } & \\
\text { - Menggunakan rumus yang } \\
\text { bersesuaian dengan apa yang } \\
\text { ditanyakan. }\end{array}$ \\
\hline
\end{tabular}

Berdasarkan hasil tes aritmatika sosial yang diberikan dan wawancara dengan siswa menunjukkan bahwa siswa mengalami kesulitan dalam menyelesaikan soal aritmatika sosial yang diberikan. Kesulitan siswa berupa kesulitan tentang pemahaman konsep, fakta, keterampilan dan prinsip yang terkait dengan persoalan aritmatika sosial. Adapun kesulitan yang dihadapi oleh subjek dalam pemahaman konsep ialah menyatakan suatu konsep PPN, bunga dan sebagainya. Siswa kesulitan dalam mengklasifikasikan soal yang diberikan dengan materi yang ada pada aritmatika sosial. Siswa juga kesulitan dalam menyajikan konsep saat mencari promo dan PPN dalam representasi matematika, kesulitan dalam penggunaan rumus yang akan digunakan dalam menyelesaikan soal, dan siswa menambahkan satuan harga dengan berat. Hal ini susai dengan indikator pemahaman konsep menurut Yustisia (Sari, 2017) yaitu: menyatakan ulang suatu konsep, mengklasifikasikan objek-objek menurut sifat tertentu dan menyajikan konsep dalam berbagai bentuk representasi matematika. Kesulitan siswa terkait faktanya meliputi kesulitan dalam penulisan simbol seperti penulisan simbol nilai jutaan, simbol \% $\%$, bunga dan sebagainya. Hal ini sesuai dengan fakta menurut Gazali (2016) yang menyatakan fakta merupakan suatu konveksi atau kesepakatan dalam matematika, ide dalam matematika yang disajikan dalam katakata, lambang (simbol) matematika.

Kesulitan siswa yang terkait dengan keterampilan meliputi kesulitan siswa dalam operasi hitung perkalian, penjumlahan dan penulisan tempat bilangan, serta kesulitan siswa dalam mengoperasikan penjumlahan nilai jutaan. Hal tersebut sesuai dengan indikator menurut Suartini, Dantes \& Widiartini (2015) terkait kemampuan mengoperasikan operasi hitung penjumlahan, pengurangan, perkalian dan pembagian.

Kesulitan siswa terkait dengan prinsipnya seperti siswa tidak mengingat rumus yang digunakan, siswa tidak memahami konsep dan lambang yang digunakan, siswa tidak dapat menggunakan rumus yang bersesuaian dengan apa yang ditanyakan dari soal, hal itu sesuai dengan Shadiq (Andar \& Ikman, 2016) menyatakan siswa memahami prinsip jika siswa tersebut ingat rumus atau prinsip yang bersesuaian, memahami seberapa konsep yang digunakan serta lambang atau notasinya, dan mampu menggunakan rumus atau prinsip yang bersesuaian pada situasi yang tepat.

Pemahaman konsep, fakta, keterampilan dan prinsip yang dikemas dalam soal tersebut sesungguhnya telah diajarkan kepada siswa, namun dalam menyelesaikan soal aritmatika sosial yang diberikan, siswa cenderung melupakan konsep, fakta, keterampilan dan prinsip yang telah diajarkan sebelumnya. 


\section{$\pi$ (Phi)}

Kelupaan siswa tersebut menunjukkan bahwa siswa tidak memahami konsep, fakta, keterampilan dan prinsip yang berkaitan dengan persoalan aritmatika sosial yang diberikan. Hal ini menunjukkan pada hasil tes aritmatika sosial siswa banyak melakukan kesalahan, kesalahan yang dilakukan dalam menyelesaikan persoalan aritmatika sosial menandakan siswa mengalami kesulitan dalam mempelajari aritmatika sosial. Hubungan antara kesalahan dan kesulitan dapat dilihat pada kalimat "jika seseorang siswa mengalami kesulitan maka ia akan membuat kesalahan". hal ini sesuai dengan penelitian menurut Hidayati (2010) dengan demikian dapat dikatakan memang benar siswa mengalami kesulitan dalam mempelajari aritmatika sosial.

Dengan kesulitan yang dihadapi oleh siswa maka siswa diharapkan lebih memahami konsep dalam aritmatika sosial, membiasakan dalam penulisan dan penggunaan fakta matematika yaitu disiplin dalam penggunaan simbol yang digunakan. Siswa diharapkan sering berlatih dalam keterampilan yang digunakan seperti keterampilan dalam opersi hitung penjumlahan, pengurangan, perkalian dan pembagian. Siswa yang memahami konsep dan lambang yang digunakan akan paham dengan prinsip yang ia akan gunakan.

\section{SIMPULAN DAN SARAN}

Berdasarkan hasil tes soal aritmatika sosial dan hasil wawancara yang diberikan kepada siswa SMP Negeri 11 Muaro Jambi maka dapat disimpulkan bahwa. Siswa mengalami kesulitan dalam pemahaman konsep, fakta, keterampilan dan prinsip. Siswa yang mengalami kesulitan dalam pemahaman konsep seperti kesulitan saat menyatakan ulang suatu konsep. Kesulitan dalam mengklasifikasikan soal yang diberikan berkaitan dengan yang ada pada materi, siswa hanya menyatakan satu materi dari

dua materi yang terkait pada soal yang diberikan. Kesulitan dalam menyajikan konsep pada berbagai representasi matematika, siswa mengoperasikan satuan harga dengan berat serta mengoperasikan langsung satuan harga dengan bentuk persen.

Kesulitan siswa terkait dengan fakta matematika meliputi kesulitan dalam penulisan beberapa simbol yang digunakan. Kesulitan siswa terkait dengan keterampilan dapat dilihat dari kesulitan siswa dalam operasi hitung perkalian, penjumlahan, dan penulisan nilai tempat bilangan, serta kesulitan dalam mengoperasikan penjumlahan nilai jutaan. Kesulitan siswa terkait dengan prinsip dapat dilihat antara lain siswa tidak mengingat rumus yang digunakan, siswa tidak memahami konsep dan lambang yang digunakan, siswa juga tidak menggunakan rumus yang bersesuaian dengan apa yang ditanyakan dari soal yang diberikan.

Bagi Mahasiswa Pendidikan Matematika Stara 1, agar dapat melakukan penelitian sejenis dengan menggunakan materi selain aritmatika sosial dalam matematika. Bagi Peserta Didik, peserta didik diharapkan memperbanyak latihan soal, menayakan pada guru apabila belum faham dengan materi yang diterangkan guru, dan menumbuhkan motivasi untuk belajar terutama pada pokok bahasan aritmatika sosial. Bagi Guru, guru diharapkan memberikan motivasi belajar kepada peserta didik agar peserta didik mempunyai perhatian dan minat dalam belajar matematika, dan memperbanyak memberikan latihan soal pada pokok bahasan aritmatika sosial.

\section{DAFTAR PUSTAKA}

Andar, Ikma. 2016. Deskripsi Kesalahan Siswa dalam Menyelesaikan Soalsoal Ujian Semester Matematika Siswa Kelas VIII SMP Negeri 10 
Kendari. Jurnal Penelitian Pendidikan Matematika. 4.2.

Arikunto, S. 2014. Prosedur Penelitian Suatu Pendekatan Praktik: Jakarta. Rineke Cipta.

Djamarah, S. B. 2011. Psikologi Belajar edisi revisi 2011. Jakarta: Rineke Cipta.

Gazali, R. Y. 2016. Pembelajaran Matematika yang Bermakna. Math Didactic: Jurnal Pendidikan Matematika. 2.3. ISSN 2442-3041.

Hidayah, S. 2016. Analisis Kesalahan Siswa dalam Menyelesaikan Soal Cerita SPLDV Berdasarkan Langkah Penyelesaian Polya. Prosiding Seminar Nasional Pendidikan Matematika.1. ISSN 2528-259X.

Sari, E. F. P. 2017. Pengaruh Kemampuan Pemahaman Konsep Matematika Mahasiswa Melalui Metode Pembelajaran Learning Starts With A Question. Jurnal "Mosharafa". $6, .1$

Suartini, A. S. Dantes, N. dan Widiartini, K. 2015. Pengaruh Implementasi Pendekatan Pembelajaran Kontekstual Terhadap Prestasi Belajar Matematika dengan Kovariable Kemampuan Numerik Pada Siswa Kelas VI SDN Gugus Sukawati 1. e- Jurnal Program Pascasarjana Universitas Pendidikan Ganesha Program Studi Penelitian dan Evakuasi Pendidikan. 5.1

Sugiyono 2009. Metode Penelitian Bisnis (Pendekatan Kuantitatif, Kualitatif, dan $\quad R \& D) . \quad$ Bandung: ALFABETA

Sugiyono. 2017. Metode Penelitian Kuantitatif, Kualitatif, dan $R \& D$. Bandung: ALFABETA.

Tim penyusun. 2015. Buku Panduan Penulisan Skripsi FKIP Universitas Batanghari. Jambi:Universitas Batanghari. 